\title{
Climate Change Resistant Energy Sources for Global Adaptation
}

\author{
Oluwatobi Ololade Ife-Adediran and Oluyemi Bright Aboyewa
}

\section{Contents}

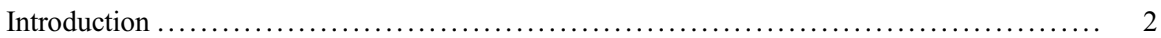

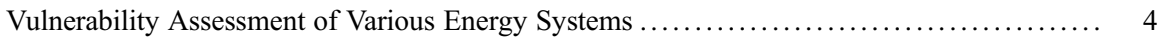

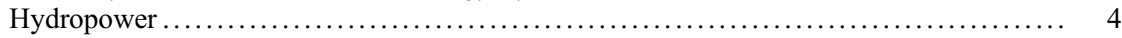

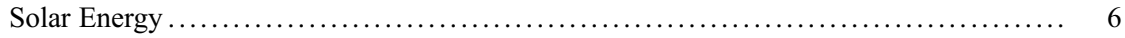

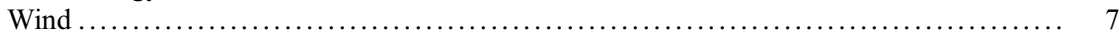

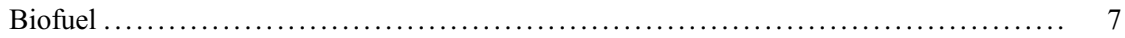

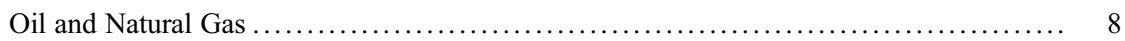

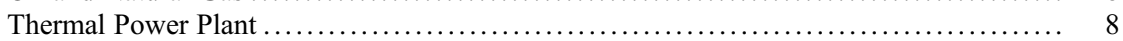

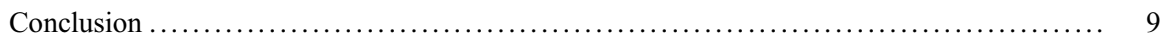

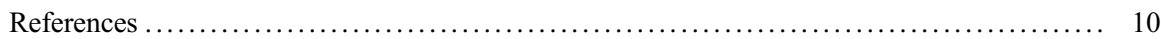

\section{Abstract}

A holistic response and adaptation to climatic vicissitudes and extreme conditions as well as their associated risks to human and ecological sustainability must adequately cater for energy needs and optimization. An interventional approach should, among other measures, seek to improve the resilience of existing and prospective energy systems to climate change. The structured and policy-driven

This chapter was previously published non-open access with exclusive rights reserved by the Publisher. It has been changed retrospectively to open access under a CC BY 4.0 license and the copyright holder is "The Author(s)". For further details, please see the license information at the end of the chapter.

O. O. Ife-Adediran ( $ه)$

Geochronology Division, CSIR-National Geophysical Research Institute (NGRI),

Hyderabad, India

Department of Physics, Federal University of Technology Akure, Akure, Ondo State, Nigeria e-mail: tobireliable@yahoo.com

O. B. Aboyewa

Department of Physics, College of Arts and Sciences, Creighton University, Omaha, NE, USA 
nature of adaptation measures require a bottom-up proactive approach that envisages the performance and efficiency of these systems, especially in terms of their sensitivity and vulnerability to changing climate conditions. Therefore, this chapter seeks to scrutinize various sources of energy concerning their resistance capabilities to climate change in the face of increasing global energy demands and consumption. Renewable and conventional energy sources are coexamined and compared vis-à-vis the current trends and predictions on climatic factors that are bearing on their principles of production, supply, and distribution. Findings from this article will serve as assessment tools for decision makers and corroborate other ongoing discourse on climate actions towards socioeconomic development and a sustainable environment.

\section{Keywords}

Climate change $\cdot$ Extreme conditions $\cdot$ Energy resources $\cdot$ Sustainability optimization

\section{Introduction}

Energy represents a fundamental requirement for wealth and job creation in many parts of the world. For many decades, humans have leveraged on the conversion of chemical energy in fossil fuels to other forms of energy. Unfortunately, these energy conversions are accompanied by the release of gases into the atmosphere and this has gradually engendered climate change; hence, the recent emphasis on energy policy alterations that factor sustainable energy supply and environment (Bang 2010). On a global scale, climate change poses increasingly severe risks on the ecosystem; the effect is particularly telling on human health, environmental safety, agriculture and economy. These changes are mostly as a result of the release of large amounts of greenhouse gases (GHG) into the atmosphere. These gases result from anthropological activities all over the world, such as burning fossil fuels for electricity and heat generation, as well as the use of internal combustion engines for transportation (EEA 2017). According to the 2019 report of the International Renewable Energy Agency (IRENA), despite the actions towards global energy transformation, carbon dioxide $\left(\mathrm{CO}_{2}\right)$ emissions that are related to the energy sector, have increased annually by over 1\% on average from 2013 and 2018 (IRENA 2019). The European Environment Agency also submits that the energy sector, especially in relation to utilization of fossil fuels, lies at the heart of the challenges that are associated with climate change (EEA 2017). In fact, the utilization of energy by humans constitutes the largest contribution to the emission of greenhouse gases. The Energy Sector Management Assistance Program (ESMAP) presents the urgency of actions to control emissions and the necessity to adapt to unavoidable climate effects from the damage already induced in the biosphere due to anthropogenic GHG emissions. Energy generation and utilization do not only contribute to climate change due to greenhouse gas (GHG) emissions but are also directly influenced by its adverse effects (EUEIPDF 2017). 
Environmental concerns will largely influence the generation, supply and utilization of energy in the near future; hence, the interest in alternative fuels and improvement in energy conversion technologies (Bauen 2006). In a broad sense, climate change affects energy supply and demand in terms of endowment, exploitation infrastructure and transportation. The effect of climate change on energy security ripples to other sectors such as socioeconomy, industry, and biodiversity (Ebinger and Vergara 2011). More specifically, in 2005, climate change resulted to over $10 \%$ variation in energy yield in developing countries (World Bank 2009). Changes in climatic parameters are evidential and can be observed in the lower atmospheric conditions, sea level and surface temperatures as well as topsoil wetness or dryness (Ebinger and Vergara 2011). Some predictions by the Intergovernmental Panel on Climate Change (IPCC) include an increase in global average temperature by close to $5{ }^{\circ} \mathrm{C}$ by the end of the century, fluctuating precipitation patterns and intensity, recurring extreme weather events and sea-level expansion (EUEIPDF 2017). Changes in ambient air temperature will affect the energy required for heating and cooling applications. Storms are notable for the destruction of electricity distribution infrastructure and this is being mitigated through underground cable networks. In relation to overcoming the adverse effects of climate change on clean energy generation, Bauen (2006) opined that there is great need for ingenuity, research, investment, and regulations.

Among other merits, renewable energy plays a crucial role in future low-carbonemission plans aimed at mitigating global warming. When combined with improved energy efficiency, renewable energy is capable of achieving a 75\% reduction in energy-related $\mathrm{CO}_{2}$ emission (IRENA 2019). Bhuiyan et al. (2018) suggested that conservation of biodiversity and environmental sustainability require the exploitation of different renewable energy sources. However, the dependence of renewal energy exploration on and climatic conditions and susceptibility to climate change is a significant area of concern (Ebinger and Vergara 2011). This is in addition to their relatively high cost of generating electricity and uneven natural distribution cum availability. In principle, the adaptation of energy systems is primarily aimed at sustainable energy supply as well as balance between energy production and consumption under varying temporal and spatial conditions (IPCC 2007). However, in reality, climate variability and extremes represent the most significant threat to the entire energy supply chain. Some future projections reveal that the energy sector will become increasingly susceptible to climate change; hence, the need for effective adaptive measures (Ebinger and Vergara 2011).

Energy adaptation in the face of climate change requires reliable and sufficient weather and meteorological data, forecast models and modalities for the performance evaluation assessment of energy systems (Troccoli 2009). Climate change impacts are envisaged throughout the energy system; affecting both demand and supply. There are associated changes in demand patterns for heating and cooling due to rising temperatures. On the supply end, impacts include changes in wind direction and intensity, solar and hydropower resources, the available crops as raw materials for biomass energy production, costs and accessibility of fossil fuels in the face of frozen sea water and permafrost, the efficiency of Photovoltaic systems, thermoelectric power plants and cable systems due to increasing temperatures, as well as 
operational downtime due to the occurrence of extreme weather events (Cronin et al. 2018). In low income countries, energy supplies are unstable as a result of the relatively high dependence on hydroelectricity and biomass energy which are contingent on rainfall patterns and intensity (Ebinger and Vergara 2011).

Although there is an increased focus on investigating the impact of climate change on energy systems, the formal knowledge base appears to be limited (Wilbanks et al. 2007; Schaeffer et al. 2012). More importantly, studies are based on scenario analysis rather than predictions and are hindered by inherent uncertainties in modeling tools (Schaeffer et al. 2012). There are significant uncertainties that are associated with future climate projections and its effect on energy systems (Schaeffer et al. 2012). This paper seeks to scrutinize various energy sources, especially concerning their resistance capabilities to climate change using existing research database on global and regional predictions on the vulnerability assessment of energy systems. Renewable (hydropower, wind, solar energy, biofuel etc.) and fossil energy (oil and natural gas) sources are co-examined and compared vis-à-vis the current trends and predictions on climatic factors that are bearing on their principles of production, supply and distribution.

\section{Vulnerability Assessment of Various Energy Systems}

\section{Hydropower}

Hydropower contributes significantly to total and per capita energy supply in many countries as a prominent renewable and primary energy source of electricity. The main requirement for the production of hydropower is runoff, which is largely dependent on rainfall (Hamududu and Killingtveit 2012). In view of the absolute dependence of hydropower on water resources, countries that depend largely on this source of energy experience a seasonal variation in the production of electricity (Teotónio et al. 2017; Rübbelke and Vögele 2012). Climate variability will definitely affect precipitation rate and regularity (Costa et al. 2012; Turner et al. 2017), which in turn affects hydroelectric power generation through changes in river flow, water storage, and downstream energy production (Tapiador et al. 2011; Teotónio et al. 2017). Apart from the direct effects, climate change can indirectly affect hydropower generation as a result of competitive demands and pressure on water resources by non-energy based economic sectors such as agriculture. Climate change can also engender contentions regarding water resource allocation and utilization between countries that jointly possess river catchments (Teotónio et al. 2017). Water reservoirs enhance the management of transient flow events and changes in river flow intensities (Lehner et al. 2005; Gaudard and Romerio 2014; Teotónio et al. 2017). Inter-seasonal water storages can also be adapted as resilience measures against the effect of climate change on hydropower. The effect of climate change on hydropower depends on the depths and surface areas of dams. The evaporation potential of shallow and wide dams makes them vulnerable to climate change as a result of the heat associated with global warming and the consequent increase in evaporation and drought intensity (Mukheibir 2013; Trenberth 2011; Teotónio et al. 2017). 
Studies related to climate change impacts on hydropower can be done using different methods, with data that are assessed globally, regionally, or locally. Predictive impact assessments can also be carried out using modeling techniques. Although large scale analyses demonstrate inherent uncertainties based on modeling choices, they, however, provide tools for assessing global vulnerability hotspots. More impressive accuracies are achieved with models that are developed using data obtained from regions with similar climatic conditions (Turner et al. 2017). Some studies and projections found in literatures are reported as follows; Hamududu and Killingtveit (2012) used a group of simulated regional patterns of variations in runoff, which were generated from global circulation models (GCM), to estimate changes in global hydropower generation resulting from predicted changes in climate. The evaluation showed that significant impacts of climate change on hydropower generation, especially from existing power systems, is more probable on a country or regional level than a global scale. On the contrary, a recent study by van Vliet et al. (2015), using an integrated modeling and data framework on existing hydropower power plants, forecasted a decrease in usable output for more than half of the hydropower plants worldwide for a period of thirty (30) years starting from 2040. Unlike previous studies that adopted the coupled hydrological electricity modeling method on a small scale, van Vliet et al. (2015) utilized this model to establish the effect of climate change and varying water resources on global electricity supply in the twenty-first century. It is apparent that results of localized predictions of the effect of climate change on the generation of hydropower should be carefully interpreted and cannot be generalized. Furthermore, the generalization of parameters that have high spatial variation should be avoided (Schaefli 2015; Turner et al. 2017).

Turner et al. (2017) identified regions with projected significant losses in hydropower production using a coupled, global hydrological and dam operating model with three GCM projections for two emissions frameworks. The global vulnerability hotspots that were identified include; the countries of southern Europe that surround the Mediterranean Sea, as well as those within North Africa and the Middle East region. In a local study, Teotónio et al. (2017) employed an optimization model to predict the impact of climate variation on the availability of water resources and the electrical power generation in Portugal. Findings from the study showed that by 2050, hydropower generation may fall significantly and lead to higher costs of electricity in the study location as a result of climate. This result is corroborated by a similar analysis carried out by Carvajal et al. (2017) in Ecuador, which revealed that hydropower generation is relatively unstable and vulnerable to climate change since variations in throughput to hydropower stations would result in changes in the expected hydropower generation, given stable conditions.

While hydropower exploitation contributes to low carbon development initiatives, reduction in plant output due to drying climate conditions engenders the dependence on fossil fuels especially when other renewable energy sources are not competitive (Spalding-Fecher et al. 2017). The resistance of hydropower plants to climate change and its consequent effect on availability of freshwater resources can be enhanced through improvements in plant efficiency, cooling systems and fuel switches (van Vliet et al. 2015). Recently, the International Hydropower Association 
(IHA), presented a six-phase approach to climate resilience for the hydropower sector which includes; comprehending what climate resilience means for the sector, a first phase of qualitative assessment of the project to climate risks, an initial or preliminary analysis, a climate stress test, risk management planning, and lastly the monitoring, evaluation and reporting of the outcomes of each of the phases (IHA 2019).

\section{Solar Energy}

Solar power ranks as the third most utilized renewable energy (after hydropower and biomass energy) and constitutes an increasingly essential component of the future low carbon-energy campaign across the globe (Panagea et al. 2014). Solar energy is mostly harnessed for both heating and electricity generation through active or passive energy systems which utilize solar collectors, photovoltaics, power towers, solar ponds, or ocean thermal collection. Through the Photoelectric effect, solar cells are utilized in the direct conversion of solar radiation to electricity; conversion efficiencies above $20 \%$ can be achieved through technologies that concentrate the incident light rays (Patt et al. 2013). The efficiency of Photovoltaic (PV) systems can be primarily influenced by geometry, ageing, ambient conditions, environmental pollution, as well as electrical, visual, and shade losses (Skoplaki and Palyvos 2009; Mani and Pillai 2010; Meral and Diner 2011; Panagea et al. 2014). The output of PV cells has a nearly linear inverse relationship with cell temperature and a directly proportional response total irradiance. Hailstorms can also affect the performance and most notably, the physical components of PV systems (the PV modules). Some of the existing solar energy technologies such as pump or circulation systems are used in environments with extreme freezing or overheating temperatures.

The impact of climate change on temperature and irradiance will significantly affect PV output (Crook et al. 2011). Climate change effects have a bearing on atmospheric transmissivity by changing atmospheric water vapor content, cloudiness (Cutforth and Judiesch 2007), and its aerosols content (Gaetani et al. 2014). Generally, the efficiency of PV modules drops by about $0.5 \%$ per degree Celsius rise in temperature (Patt et al. 2013). A study by Crook et al. (2011) utilized data obtained from coupled ocean-atmosphere climate models to indicate that PV output from 2010 to 2080 will change slightly in Algeria and Australia while it will probably rise or reduce in some parts of North America, Europe, and Asia. In another study conducted by Gaetani et al. (2014) using climate-aerosol modeling experiments, the results showed that by 2030 , there will be varied effects of climate change on the production of photovoltaic energy in different parts of the world; this result is consistent with that of Crook et al. (2011). In Greece, there is an inverse relationship between the output of PV devices and the predicted rise in annual temperature, which is exceeded by the projected increase of total radiation resulting in a net increase in energy output (Panagea et al. 2014). Further location-specific studies are required for quantitative assessments of climate impacts on PV systems (Patt et al. 2013). 


\section{Wind}

Wind energy is well explored for electricity generation, but it is not insulated from the influence of climatic vicissitudes since its energy density depends on global energy balance and the consequent atmospheric motion (Pryor and Barthelmie 2010; Schaeffer et al. 2012). The energy output from wind has a cubic relationship with the speed of the moving air mass, and it is proportional to air density (Manwell et al. 2002; Pryor and Barthelmie 2010). A differential change in wind speed will affect its potential for electricity production, timing, and the operational period of wind plant (Pasicko et al. 2012). According to Baker et al. (1990), a 10\% change in the average wind speed could alter energy production by up to one-quarter of its initial capacity. Hence increase in wind speeds as a result of climate change should result in increased energy outputs and this could translate to an increased dependence on this energy source. Wind turbines are carefully structured to factor transient wind conditions such as the occurrence of extreme wind speeds, and other aerodynamics such as directional variations (DNV 2002). The reliability and safety of a wind power plant is determined by the maximum wind speed for which it is designed (Pasicko et al. 2012). Wind turbines should be kept nonoperational during conditions that exceed their reliability and safety indexes in other to avoid infrastructural damages.

Wind speed varies significantly with elevation from sea level as well as the spatial density of natural and artificial wind breakers (Ebinger and Vergara 2011). Several other variables can impact the vertical profile of a moving air mass, and the extrapolation of wind speeds at heights where they are not measured is quite convoluted. The logarithmic extrapolation method is popularly adopted in the estimation of wind speeds at hub heights of wind turbines that are above $50 \mathrm{~m}$ (Schaeffer et al. 2012). The consideration of the terrain roughness is characteristic of this method of estimation. With regards to wind energy, the roughness of a terrain is dependent on vegetative cover which can be significantly affected by climate changes and consequently impact the generation of wind power (Lucena et al. 2010; Schaeffer et al. 2012). As such, the development of wind energy production requires reliable information about the potential variations in wind energy availability as well as topographical parameters in a location of interest (Bloom et al. 2008).

\section{Biofuel}

Bioenergy (which is generated from crops are such as jatropha, sunflower, cotton, sugarcane, sorghum, and maize) is a vast and diverse energy source category since it consists of a wide range of organic fuels that can be adapted to various types of technologies to run engines, produce heat or generate electricity (Kirsten 2012). Perennials with suitable land cover are preferable as energy crops. Oilseeds are particularly used as pure plant oil and for biodiesel production while sugarcane and cereals are used in some parts of the world for the production of bioethanol as alternatives to gasoline for engines such as automobiles (Kirsten 2012), thereby 
portending significant contribution to the reduction of carbon footprint from transportation. The sustainability of biodiesel remains a debate as most studies come to a wide range of conclusions due to differences in approach, biomass input sources, land use and its associated change impacts, choice of system limits and functional units, as well as the methods that are adopted for allocation (Rouhany and Montgomery 2019). However, it is apparent that climate change has its toll on bioenergy production. For instance, liquid biofuels are indirectly susceptible to changes in temperature and rainfall patterns, as well as available $\mathrm{CO}_{2}$ to crops which serve as feedstock for the production of transportation biofuels (Schaeffer et al. 2012). Average crop yields and arable land suitable for growing bioenergy crops are affected by rising temperatures and changing precipitation patterns (EUEIPDF 2017; Cronin et al. 2018). Some specific resulting adverse effects in this regard are land-area losses due to flood, salinity and dry-out influences of increased temperature (Mohammad 2013). For plants, $\mathrm{CO}_{2}$ is an essential greenhouse gas because of its necessity for photosynthetic process. Haberl et al. (2011) explicitly examined mean cropland yield change under climate change in 2050 with and without $\mathrm{CO}_{2}$ fertilization, and the findings indicated regional variation and increase as high as $28.22 \%$ in crop yield with full $\mathrm{CO}_{2}$ fertilization and considerable loss (up to $-16.02 \%)$ when this effect is controlled.

\section{Oil and Natural Gas}

The primary concerns regarding the utilization of fossil fuels are related to their depletion, future exhaustion, and carbon emission. Oil and gas conventional energy deposits are not likely to be affected by climate change due to their long-term formation process in geological traps (Ebinger and Vergara 2011). However, there could be indirect effects on the utilization of these resources especially with regards to the identification of natural reserves and accessibility to them (Schaeffer et al. 2012). Climate change events can affect oil and gas exploration, processing and transportation (Burkett 2011). Hurricanes and other extreme climatic events can hamper the production of these fossil fuels from off-shore facilities (Ebinger and Vergara 2011). Similarly, Burkett (2011) identifies that changes in climate variables such as sea and $\mathrm{CO}_{2}$ levels, intensity of storms, wave regime, air and water temperature, rainfall patterns and ocean acidity also can affect oil and gas exploration in coastal regions (Schaeffer et al. 2012). There are also predictions that significant reduction in ice cover may increase the feasibility of exploration in areas of the Arctic (Harsem et al. 2011; Ebinger and Vergara 2011; Schaeffer et al. 2012), raising the prospect for oil and gas development in this region.

\section{Thermal Power Plant}

The impacts of climate change on thermal power plants are mainly related to generation cycle efficiency and water needed for cooling of power plants (Wilbanks et al. 2007; Ebinger and Vergara 2011). Some technologies that could be affected in 
this regard include coal, biomass residue, and geothermal power plants (Schaeffer et al. 2012). Generally, thermal plants operate with Rankine or Brayton thermodynamic cycles, require energy for heating and cooling processes, which depend on average ambient atmospheric conditions (Schaeffer et al. 2012). Increase in temperature is likely to reduce the thermal efficiency and output of power plant (Ibrahim et al. 2014; Linnerud et al. 2011; Cronin et al. 2018). Also, expected changes in water resource availability throughout the globe will have a direct influence on the use of water for cooling existing power plants and consequently, their output capacity (Wilbanks et al. 2007). Furthermore, reduction in water resources that is available for cooling may result to load-shedding or shutdown of power stations (Cronin et al. 2018). It has been projected that by 2040 capacity reductions of $12-19 \%$ in Europe and the US are possible due to rise in water temperatures and reduction in runoff (van Vliet et al. 2012; Sieber 2013). Generally, while it is expected that changes on power plants capacity will vary according to regions (for example, increase in India and Russia); generally, global annual thermal plant capacity is likely to shrink by $7-12 \%$ in the mid-century (van Vliet et al. 2015).

\section{Conclusion}

The global concern on climate change, extreme conditions and their associated footprints are in increasingly alarming degrees, especially in recent times. In spite of the preventive and adaptive measures that have been applied at local and international fronts, it is vivid that remedial actions must be taken to supplement the efforts against the adverse effects of climate change and this study shows that the energy sector is not left out of the need for intervention. The interaction between climate change and energy adaption is significant and should be taken seriously. This paper makes a case of climate change-resistant energy utilization by examining the resilience of different energy sources to climate change, through a retrospective consideration of relevant findings from literatures on energy resources, needs and utilization as well as climatic factors, their current trends and future prediction. Consequently, it explicates the dire need for adaptive measures towards energy utilization in the face of climate changes and severe conditions. Climate change has direct and indirect effects on the exploitation of conventional and non-conventional energy resources. The effect of climate change on water resources and temperature seems to have the most significant effect on different energy sources and technologies. Extreme weather events such as hurricanes and hailstorms are detrimental to the energy systems with relatively fragile structures especially for renewable energy exploitation. This study reveals that there are temporal variations in the effect of climate change on energy systems in different parts of the world. Hence, local conditions must be considered in decision-making with regards to climate change and energy. It is hoped that this discussion provides an adequate injection of pooled examinations of different energy sources towards the sustainability and optimization of their utilization in response to climate change. 


\section{References}

Mohammad Ali (2013) Climate change impacts on plant biomass growth. Springer, Dordrecht/Heidelberg/New York, pp 29-41

Baker RW, Walker SN, Wade JE (1990) Annual and seasonal variations in mean wind speed and wind turbine energy production. Sol Energy 45(5):285-289

Bang G (2010) Energy security and climate change concerns: triggers for energy policy change in the United States? Energy Policy 38:1645-1653

Bauen A (2006) Future energy sources and systems - acting on climate change and energy security. J Power Sources 157:893-901

Bhuiyan AM, Jabeen M, Zaman K, Khan A, Ahmad J, Hishan SS (2018) The impact of climate change and energy resources on biodiversity loss: evidence from a panel of selected Asian countries. Renew Energy 117:324-340

Bloom A, Kotroni V, Lagouvardos K (2008) Climate change impact of wind energy availability in the Eastern Mediterranean using the regional climate model PRECIS. Nat Hazards Earth Syst Sci 8:1249-1257

Burkett V (2011) Global climate change implications for coastal and offshore oil and gas development. Energy Policy 39:7719-7725

Carvajal PE et al (2017) Assessing uncertainty of climate change impacts on long-term hydropower generation using the CMIP5 ensemble - the case of Ecuador. Climate Change 144(4):611-624

Costa AC, Santos JA, Pinto JG (2012) Climate change scenarios for precipitation extremes in Portugal. Theor Appl Climatol 10:217-234

Cronin J, Anandarajah G, Dessens O (2018) Climate change impacts on the energy system: a review of trends and gaps. Clim Chang 151:79-93

Crook JA, Jones LA, Forstera PM, Crook R (2011) Climate change impacts on future photovoltaic and concentrated solar power energy output. Energy Environ Sci 4:3101-3109

Cutforth HW, Judiesch D (2007) Long-term changes to incoming solar energy on the Canadian prairie. Agric For Meteorol 145:167-175

DNV/Riso (2002) Guidelines for the design of wind turbines, 2nd edn. Jydsk cetraltrykkeri, Copenhagen. $286 \mathrm{pp}$

Ebinger J, Vergara W (2011) Climate impacts on energy systems: key issues for energy sector adaptation. World Bank, Washington, DC, pp 26-51

EUEIPDF - EU Energy Initiative Partnership Dialogue Facility (2017) Energy and climate change adaptation in developing countries. European Union Energy Initiative Partnership Dialogue Facility, Eschborn, pp 6-12

European Environment Agency - EEA (2017) Energy and climate change. European Environment Information and Observation Network (Eionet), Copenhagen, pp 1-10

Gaetani M, Huld T, Vignati E, Monforti-Ferrario F, Dosio A, Raes F (2014) The near future availability of photovoltaic energy in Europe and Africa in climate-aerosol modelling experiments. Renew Sust Energ Rev 38:706-771

Gaudard L, Romerio F (2014) The future of hydropower in Europe: interconnecting climate, markets and policies. Environ Sci Policy 43:5-14

Haberl $\mathrm{H}$ et al (2011) Global bioenergy potentials from agricultural land in 2050: sensitivity to climate change, diets and yields. Biomass Bioenergy 35(12):4753-4769

Hamududu B, Killingtveit A (2012) Assessing climate change impacts on global hydropower. Energies 5(2):305-322

Harsem O, Eide A, Heen K (2011) Factors influencing future oil and gas prospects in the Arctic. Energy Policy 39:8037-8045

Ibrahim SMA, Ibrahim MMA, Attia SI (2014) The impact of climate changes on the thermal performance of a proposed pressurized water reactor: nuclear-power plant. Int $J$ Nucl Energy 2014:1-7

IHA - International Hydropower Association (2019) Hydropower sector climate resilience guide. http://www.hydropower.org. p 7 
IPCC - Intergovernmental Panel on Climate Change (2007) Climate change 2007: synthesis report. In: Pachauri RK, Reisinger A (eds) Contribution of working groups I, II and III to the Fourth Assessment Report of the Intergovernmental Panel on Climate Change. IPCC, Geneva. 104 pp

IRENA - International Renewable Energy Agency (2019) Global energy transformation: a roadmap to 2050. The International Renewable Energy Agency, Abu Dhabi. p 9

Lehner AB, Czisch G, Vassolo S (2005) The impact of global change on the hydropower potential of Europe: a model-based analysis. Energy Policy 33:839-855

Linnerud K, Mideksa TK, Eskeland GS (2011) The impact of climate change on nuclear power supply. Energy J 32(1):149-168

Lucena AFP, Szklo AS, Schaeffer R, Dutra RM (2010) The vulnerability of wind power to climate change in Brazil. Renew Energy 35:904-912

Mani M, Pillai R (2010) Impact of dust on solar photovoltaic (PV) performance: research status, challenges and recommendations. Renew Sust Energ Rev 14(9):3124-3123

Manwell JF, McGowan JG, Rogers AL (2002) Wind energy explained: theory, design and application. Wiley, Chichester

Meral ME, Diner F (2011) A review of the factors affecting operation and efficiency of photovoltaic based electricity generation systems. Renew Sust Energ Rev 15(5):2176-2184

Mukheibir P (2013) Potential consequences of projected climate change impacts on hydroelectricity generation. Climate Change 121:67-78

Panagea IS et al (2014) Climate change impact on photovoltaic energy output: the case of Greece. Adv Meteorol 201:1-11

Pasicko R, Brankovi C, Simic Z (2012) Assessment of climate change impacts on energy generation from renewable sources in Croatia. Renew Energy 46:224-223

Patt A, Pfenninger S, Lilliestam J (2013) Vulnerability of solar energy infrastructure and output to climate change. Climate Change 121:93-10.2

Pryor SC, Barthelmie RJ (2010) Climate change impacts on wind energy: a review. Renew Sust Energ Rev 14(1):430-437

Rouhany M, Montgomery H (2019) Global biodiesel production: the state of the art and impact on climate change. In: Tabatabaei M, Aghbashlo M (eds) Biodiesel. Biofuel and Biorefinery Technologies, vol 8. Springer, Cham. https://doi.org/10.1007/978-3-030-00985-4_1

Rübbelke D, Vögele S (2012) Short-term distributional consequences of climate change impacts on the power sector: who gains and who loses? Climate Change 116:191-206

Schaeffer R, Szklo AS, Pereira de Lucena AF, Cesar M, Borba BS, Pupo Nogueira LP, Fleming FP et al (2012) Energy sector vulnerability to climate change: a review. Energy 38:1-12

Schaefli B (2015) Projecting hydropower production under future climates: a guide for decisionmakers and modellers to interpret and design climate change impact assessments. Wiley Interdiscip Rev Water 2(4):271-289

Sieber J (2013) Impacts of and adaptation options to extreme weather events and climate change concerning thermal power plants. Clim Chang 121:55-66

Skoplaki E, Palyvos JA (2009) On the temperature dependence of photovoltaic module electrical performance: a review of efficiency/power correlations. Sol Energy 83:614-624

Spalding-Fecher R, Joyce B, Winkler H (2017) Climate change and hydropower in the Southern African power pool and Zambezi River basin: system-wide impacts and policy implications. Energy Policy 103:84-97

Tapiador FJ, Hou AY, de Castro M, Checa R, Cuartero F, Barros AP (2011) Precipitation estimates for hydroelectricity. Energy Environ Sci 4:443548

Teotónio C, Fortes P, Roebeling P, Rodriguez M, Robaina-Alves M (2017) Assessing the impacts of climate change on hydropower generation and the power sector in Portugal: a partial equilibrium approach. Renew Sust Energ Rev 74:788-799

Trenberth KE (2011) Changes in precipitation with climate change. Clim Res 47(1/2):123-138

Troccoli A (2009) Climate and the development community. Weather 64(1):25-26

Turner SWD, Yi J, Galelli S (2017) Examining global electricity supply vulnerability to climate change using a high-fidelity hydropower dam model. Sci Total Environ 591:663-675 
Kirsten Ulsrud (2012) Bioenergy and sustainable adaptation to climate change in Africa. In: Janssen R, Rutz D (eds) Bioenergy for Sustainable Development in Africa. Springer, Dordrecht, pp 299308

van Vliet MTH, Yearsley JR, Ludwig F et al (2012) Vulnerability of US and European electricity supply to climate change. Nat Clim Chang 2(9):676-681

van Vliet MTH, Wiberg D, Leduc S, Riahi K (2015) Power-generation system vulnerability and adaptation to changes in climate and water resources. Nat Clim Chang 6:375-380

Wilbanks TJ, Bhatt V, Bilello DE, Bull SR, Ekmann J, Horak WC, Huang YJ, Levine MD, Sale MJ, Schmalzer DK, Scott MJ, Wright SB (2007) Introduction. In: Effects of climate change on energy production and use in the United States, a report by the U.S. Climate Change Science Program and the Subcommittee on Global Change Research, Washington, DC

World Bank (2009) World development report 2009: Reshaping economic geography. The World Bank, Washington, DC

Open Access This chapter is licensed under the terms of the Creative Commons Attribution 4.0 International License (http://creativecommons.org/licenses/by/4.0/), which permits use, sharing, adaptation, distribution and reproduction in any medium or format, as long as you give appropriate credit to the original author(s) and the source, provide a link to the Creative Commons license and indicate if changes were made.

The images or other third party material in this chapter are included in the chapter's Creative Commons license, unless indicated otherwise in a credit line to the material. If material is not included in the chapter's Creative Commons license and your intended use is not permitted by statutory regulation or exceeds the permitted use, you will need to obtain permission directly from the copyright holder.

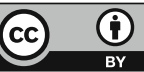

